\title{
Life cycle of innovation and assessment of intellectual property value in enterprises
}

\author{
$M$ A Makhkamova ${ }^{1}$ \\ ${ }^{1}$ Tashkent State Technical University named by Islam Karimov, Tashkent, Uzbekistan
}

\begin{abstract}
The article examines the theoretical issues of the implementation of the life cycle of innovation and practical methods for assessing the loss of value of intellectual property in enterprises in the market. The method of the cost approach is disclosed, which assumes the accounting of the costs of reproduction of the assessed intellectual property in current prices, minus depreciation, as the most effective method for assessing intellectual property. Also considered are the rates of depreciation of fixed assets of industrial facilities, the coefficients of revaluation of the cost of fixed assets, depending on their depreciation. The article proposes the author's approach to the gradation of the assessment of the lost usefulness of intellectual property in percentage and the relationship between the stages of the life cycle of an innovation and the state of the assessment of intellectual property..
\end{abstract}

Keywords. innovation, innovation process, life cycle, intellectual property, industrial facilities, assessment of loss of value, cost method, wear, utility, gradation, innovation , capital..

\section{Introduction}

The market economy is based on the use of high technologies, which presuppose the use of certain objects of intelligence for the total property. Therefore, the intelligent market allows providing conditions for a highincome sector of the economy that uses renewable intellectual resources.

The most important type of capital that modern companies have is the knowledge and experience of their employees, which have a common name - intellectual capital (IC). This type of capital, as world practice shows, provides many companies with significant competitive advantages, since it is intellectual knowledge that makes it possible to develop and introduce new types of competitive products, effectively organize the processes of its production and sale, as well as ensure the company's interaction with its suppliers, contractors, investors and customers. The basis of intellectual capital is intellectual property.

Intellectual property (IP) is the exclusive right to use the result of intellectual creative activity in the form of an object reproduction of an invention made or in the form of copies of a work of art made in any form that later allows vii restore these works.

The use of the rights of ownership of an object of intellectual property means, first of all, obtaining real or patent income from its copying (repetition, reproduction). Due to the reproduction of a technical or artistic solution and the subsequent sale of products, a source of income is formed that has obvious signs of monopoly. Intellectual property right is the monopoly right of its owner. The whole point of exclusive property rights to intellectual property is to monopolize potential profits.

Legal regulation of intellectual property objects promotes the process of efficient management of innovative processes. The essence of legislation in the field of patent and copyright law allows innovative and active enterprises to provide competitive advantages, improve the innovation climate, create conditions for the widespread use of innovative results, and get the corresponding profit from the implementation of innovative products.

Methods. The article used various types of analyzes: heuristic and expert assessment, statistical grouping, correlation, economic and statistical, graphical analysis and other methods.

Results. As a market type of property, intellectual property has become the basis for the formation of the market for its objects, which is currently developing rapidly. The initial basis for the formation of this market is the significant scientific and technical potential of the country. The special market significance of intellectual property lies in the fact that its implementation is the only way to legally monopolize the production of goods and services with the highest consumer properties.

Intellectual capital as an object of ownership has advantages over the physical means of production: it is not subject to physical alienation; after the sale or transfer of information to other people or organizations, the knowledge itself is retained by the direct owners. This feature of intellectual capital gives rise to a wide flow of investments in the training of employees of intellectual labor. Therefore, today one of the most important characteristics of intellectual work is the ownership or joint ownership of it. Funds of state organizations, private firms and public funds are invested in it. Existing laws guarantee them a certain profit in the form of proceeds from direct and indirect taxes, interest, etc. The impact of intellectual capital on the income of its owners is very clear.

Since the owner and manager of the main part of non-material means of production, according to the laws of the market, acts as 
the owner or the owner of specific commodity products, he is vitally interested in the excess of demand over the supply of his products. Any monopoly represented by the state for such a demand violates the normal course of simple reproduction, and then this capital flows abroad. Usually, this situation is inherent in countries with a weak market economy. In developed countries, the objective laws of the very technology of formation of intellectual capital, its accumulation, use, as well as the terms of physical and moral wear and tear, cause high volumes of investments in this capital. The main criterion for the effectiveness of investments in this case is a high rate of return on the capital used.

It is generally accepted that the country's stable economic growth is achieved only on an innovative basis. Only in this case it is possible to realize high quality of growth, resource conservation, efficiency of production, release of competitive products.

As a concept "intellectual property" has existed since 1967 in accordance with the decision of the Stockholm Convention. It was then that the World Intellectual Property Organization (WIPO) was created. The purpose of the creation of WIPO is to give intellectual property an extraterritorial, over national character by recognizing uniform norms in the field of intellectual property, agreeing with them the basic norms of national legislation. The composition of intellectual property is determined by the Convention Establishing this Organization. According to Art. 2 of the Convention, intellectual property includes rights related to: literary, artistic and scientific images; performing activities of artists, sound recording, radio and television broadcasts; inventions in all areas of human activity; scientific discoveries; industrial designs; trademarks, service marks, trade names and commercial designations; protection from unfair competition.

Analysis. The heads of organizations and enterprises are quite well aware of the possibilities of using such objects of intellectual property (OIP) as: inventions, industrial designs, utility models, trademarks, trade names, software, etc. With regard to industrial property, enterprises, for example, solve the problems of accounting, valuation and depreciation.

Intellectual products market problem - the establishment of b projective prices intellectual goods. However large the variety and the ness of the OIP cannot solve this problem. At best, we can talk only about the development of approaches to the determination of prices of so sensible group of b OBJECTS.

Foreign experience in the appraisal of industrial property objects involves the use of the ICSOI (International Committee for Property Appraisal Standards) standard.

Legislative regulation of intellectual property objects means effective management of innovation processes. The mechanism of legislation in the field of patent and copyright law allows innovation-active enterprises to provide competitive advantages, improve the innovation climate, create conditions for the widespread use of innovative results, and receive appropriate profit from the implementation of innovative products.

Legislative regulation of property provides legal protection and protection of the use of intellectual property. The main regulatory documents that regulate the rights of enterprises in the field of intellectual property in our republic: Laws "On Trademarks, Service Marks and Appellations of Origin of Goods", "On Copyright and Related Rights", "On the Legal Protection of Computer Programs and Databases" ... In addition, intellectual property relations are regulated by the Civil Code of the Republic of Uzbekistan and the norms of international treaties in the field of intellectual property protection.

The legislative mechanism for the protection of intellectual property provides for a system of economic, social, legal methods and means of supporting innovation. In the modern world, three main types of intellectual property protection are used: patent, copyright, trademark.

It is known that the methods of the cost approach that are most frequently used in the valuation of intellectual property (IP) imply the accounting of the costs of reproduction of the assessed IP in current prices minus depreciation. The cost of own industrial property objects, which are part of the intellectual property of the enterprise, is determined on the basis of the reduced costs, including the costs of their creation, experimental development as part of equipment and technology objects where they are applied, fees for maintaining patents for intellectual property objects (OIP), advertising and marketing costs. These costs are carried out mainly at the expense of the cost of products (works, services), taking into account the rules and requirements of the "Regulations on the composition of costs for the production and sale of products (works, services) included in the cost of products (works, services), and on the procedure for the formation of financial results ". They include the costs of remuneration of workers involved in the development and implementation of intellectual property objects and bringing them into a condition ready for use in the production of products (works, services), social security contributions, other costs not related to capital costs, such as costs for the purchase of raw materials, materials, equipment and others necessary for the development, implementation and use of OIP.

Discussion. According to the valuation standards, when using the cost method:

- reveals all the actual costs associated with the creation, acquisition or implementation of the OIP;

- the costs are specified by the value of the price index as of the date of the calculations of the value of the considered IP;

- the accrued depreciation value is determined.

The value of IP rights is defined as the difference between the adjusted cost and the accrued depreciation.

The complexity of this method lies in determining the amount of depreciation, since there are no specific norms established by regulatory documents for intangible assets. The Tax Code of the Republic of Uzbekistan for the calculation of depreciation on fixed assets established the following norms (table 1.).

Expenses on intangible assets are deducted from total income in the form of depreciation. The deduction is carried out monthly according to the rates calculated by the legal entity based on the initial cost and useful life (but not more than the term of the legal entity's activity). For intangible assets, the useful life of which is impossible to determine, the depreciation rates are set per five years (up to no more than the term of the legal entity's activity).

We believe that when revaluing all assets of an enterprise from their book value to market value, the possible depreciation of these assets should be taken into account. This accounting can be done in two alternative ways: 
- alternative A: if a similar asset can be found on the market at the time of revaluation with exactly the same types of depreciation as accumulated in the revalued property, then the task of revaluation is reduced to replacing the asset's book value with the observed current market value of a similar asset;

- alternative B: if this is not possible, then all types of accumulated depreciation of the revalued asset should be taken into account separately, making special discounts from its actual cost of acquisition or creation on its own (from the original carrying amount of the asset), which would correspond to the degree of depreciation of the asset in question.

Table 1.

Depreciation rates for fixed assets in the transport system

\begin{tabular}{|c|c|c|}
\hline № & Fixed asset groups & $\begin{array}{l}\text { Depreciation } \\
\text { rate, } \%\end{array}$ \\
\hline 1. & $\begin{array}{l}\text { Passenger cars, taxis, automotive } \\
\text { vehicles for road use, special tools, } \\
\text { inventory and accessories, computers, } \\
\text { peripherals and data processing } \\
\text { equipment }\end{array}$ & 20 \\
\hline 2. & $\begin{array}{l}\text { Trucks, buses, special vehicles and } \\
\text { trailers. Machinery and equipment for } \\
\text { all industries, } \\
\text { foundry, forging equipment, } \\
\text { construction equipment, agricultural } \\
\text { machinery and equipment. Office } \\
\text { furniture. }\end{array}$ & 15 \\
\hline 3. & $\begin{array}{l}\text { Railway, sea, river and air } \\
\text { vehicles. Power machines and } \\
\text { equipment: heating equipment, turbine } \\
\text { equipment, electric motors and diesel } \\
\text { generators. Device power } \\
\text { communication. Pipelines. }\end{array}$ & 8 \\
\hline 4. & $\begin{array}{l}\text { Buildings, structures and other } \\
\text { structures. }\end{array}$ & 5 \\
\hline 5. & $\begin{array}{l}\text { Depreciable assets not elsewhere } \\
\text { classified. }\end{array}$ & 10 \\
\hline
\end{tabular}

The procedure stipulating the direct revaluation method and the index method recommended in the Regulations on the procedure for the revaluation of fixed assets (approved by the Resolution of the Ministry of Economics and Statistics of the Republic of Uzbekistan dated 02.02.2011-year No. RA01/8-6a and registered by the Ministry of Justice of the Republic of Uzbekistan on 19.02. 2011, No. 1008).

The direct revaluation method assumes a direct recalculation of the value of individual objects at documented market prices for new objects similar to those being assessed. The following can be used to document the full replacement cost of objects:

- data on prices for similar products received in writing from manufacturing organizations and their official dealers, commodity exchanges, real estate exchanges;

- data on the value of fixed assets in hard currency as of the date of acquisition (if there is a supporting document) using a calculation coefficient defined as the ratio of the rates of the Central Bank of the Republic of Uzbekistan for that period (as of the date of recalculation) and the date of acquisition of fixed assets;

- information on the price level available from the relevant government agencies;

- information about the price level published during the revaluation period in the media and special literature;

- expert opinions on the value of fixed assets.

The index method involves indexing the initial (replacement) value of individual objects using indices of changes in the value of fixed assets, differentiated by types of fixed assets and percentage of depreciation and presented in the annex of the above "Regulation ..." (Table 2). In this case, a single method is applied to homogeneous objects of fixed assets (brands, types, etc.).

Revaluation factors for fixed assets depending on their wear

\begin{tabular}{|c|c|r|r|r|r|r|}
\hline \multirow{2}{*}{$\begin{array}{c}\text { Types of } \\
\text { fixed assets }\end{array}$} & \multicolumn{5}{|c|}{$\begin{array}{c}\text { Coefficients of revaluation of the cost of } \\
\text { fixed assets, with the amount of wear }\end{array}$} \\
\cline { 2 - 7 } & $\begin{array}{c}\text { to } \\
\text { fr }\end{array}$ & $\begin{array}{c}\text { fr } \\
\text { om } \\
\text { om } \\
21 \% \\
\text { to } \\
25 \%\end{array}$ & $\begin{array}{c}\text { fr } \\
\text { om } \\
\text { to } \\
36 \%\end{array}$ & $\begin{array}{c}\text { fr } \\
\text { om } \\
\text { to } \\
55 \%\end{array}$ & $\begin{array}{c}75 \% \\
56 \% \\
\text { to } \\
75 \%\end{array}$ & $\begin{array}{c}75 \% \\
\text { above }\end{array}$ \\
\hline Building & 2.9 & 13.8 & 27.5 & 9.2 & 8.1 & 5.5 \\
\hline $\begin{array}{c}\text { Constructio } \\
\text { ns }\end{array}$ & 2.9 & 13.8 & 27.5 & 8,7 & 8.1 & 5.5 \\
\hline $\begin{array}{c}\text { Transfer } \\
\text { devices }\end{array}$ & 2.7 & 13.0 & 25.8 & 8,7 & 6.5 & 5.2 \\
\hline $\begin{array}{c}\text { power } \\
\text { machines and } \\
\text { equipment }\end{array}$ & 1.0 & 6.2 & 18.9 & 27.5 & 5.6 & 3.0 \\
\hline $\begin{array}{c}\text { working } \\
\text { machines and } \\
\text { equipment }\end{array}$ & 1.0 & 6.2 & 18.9 & 27.5 & 5.6 & 3.0 \\
\hline $\begin{array}{c}\text { tractor } \\
\text { equipment }\end{array}$ & 1.0 & 6.2 & 18.9 & 27.5 & 5.6 & 3.0 \\
\hline $\begin{array}{c}\text { Computer } \\
\text { Engineering }\end{array}$ & 1.0 & 6.2 & 18.9 & 27.5 & 5.6 & 3.0 \\
\hline $\begin{array}{c}\text { other } \\
\text { machinery } \\
\text { and } \\
\text { equipment }\end{array}$ & 1.0 & 6.2 & 18.9 & 27.5 & 5.6 & 3.0 \\
\hline $\begin{array}{c}\text { vehicles } \\
\text { tools, } \\
\text { production } \\
\text { inventory and } \\
\text { other types of } \\
\text { fixed assets }\end{array}$ & 1.0 & 6.2 & 18.9 & 27.5 & 5.6 & 3.0 \\
\hline
\end{tabular}

In the absence of specific values of the rates of depreciation (impairment) for certain types of IP and categories of intangible assets (IA), the named rates of amortization and revaluation coefficients of the cost of fixed assets can be used when assessing IP using the cost approach methods. The fairness of such application can be justified by the relevant norm of the Law of the Republic of Uzbekistan "On inventions, utility models and industrial designs". According to this norm, a product is recognized as manufactured using a patented industrial property, and a method protected by a patent for an invention is applied if it uses every feature of an invention, a utility model included in 
an independent claim, or an equivalent feature, and for an industrial sample - if the product contains all of its essential features.

But, as practice shows, such use of depreciation rates or revaluation coefficients established for fixed assets has limited application due to the difference in the nature of the OIP and the product made on its basis. All this once again exacerbates the problems of establishing for all categories of OIP and intangible assets their own norms for assessing the loss of value. The validity of accounting for the accrued amortization value, along with the determination of the useful life, raises a lot of controversy in determining the market value of IP.

As noted in the International Committee on Valuation Standards (ICSOI) "General Concepts and Valuation Principles" standard, the terminology of financial reporting does not coincide in all respects with the terminology used by appraisers. This also applies to the use of the concept of "depreciation", which can lead to confusion. For the avoidance of misunderstanding, the aforementioned ICSOI standard recommends that appraisers, when using reproduction cost and replacement cost methods, use the term "depreciation" or "accumulated depreciation" to denote any loss of value compared to its value, defined as the total cost of the corresponding new facility. Such losses can be caused by physical deterioration, functional, technical or external obsolescence.

Depreciation in appraisal activities is considered as a factor of the present value of the appraisal, irrespective of the actual (historical) cost. Depreciation is viewed as a "loss of utility," and hence value, for whatever reason.

Depreciation deductions - depreciation of fixed assets calculated in monetary terms, included in production costs and transferred to the price of goods. Depreciation deductions are determined as a share of the original cost of the property in accordance with the depreciation rates and are charged over its useful life. From this point of view, in order to determine the value of rights to IP, it is appropriate to talk about the depreciation or obsolescence of IP with the subsequent reflection of this depreciation (obsolescence) in accounting and reporting in the form of "depreciation deductions".

In fact, the term "depreciation charges" means that accountants make accruals to cover historical costs of creating or acquiring assets with an agreement that historical costs were incurred, regardless of the basis on which the accruals were made. What is important, as noted in the ICSO standard, is that for the evaluator, accumulated depreciation is market dependent; depreciation charges determined by an accounting agreement do not necessarily reflect market conditions.

Thus, from our point of view, to determine the degree of the lost value of an asset, the use of the mechanism for calculating "depreciation deductions", strictly regulated by the norms and standards of accounting and reporting, is not always justified and sometimes may lead to incorrect results. Taking into account the uniqueness of IP, adhering to the recommendations of the ICSOI, in the process of determining the replacement cost of rights to OIP, it is more expedient to adhere to the concept of depreciation or obsolescence of OIP than amortization of an intangible asset, as recommended by accounting standards. This approach is also justified because it is not so much about the transfer of the initial value of the considered IP in the prices of the product, but about the accounting of the lost utility in the Determined replacement value at a specific date of assessment.

The implementation of this approach is primarily associated with the establishment of the total useful life (service life) of the IP.

The method generally accepted in valuation practice for determining the degree of wear and tear based on the legal duration of exclusive rights is not always acceptable for assessing the value of rights to OIPs and may lead to incorrect results, especially when assessing unique OIPs. This is due to a number of circumstances, among which the following can be listed:

- a title of protection (patent, certificate) certifying the exclusive rights of the copyright holder of intellectual property during the entire period of its validity may be invalidated in whole or in part;

- the validity of the title of protection may be terminated ahead of schedule if it is recognized as invalid on the basis of an application by the patent holder and if the fees for maintaining the title of protection in force are not paid within the prescribed period. This rule also applies to trademarks: the registration of a trademark may be terminated early, in whole or in part, by the decision of the Appeal Council of the State Patent Office at the request of any person, due to nonuse of the trademark continuously for five years from the date of registration or five years preceding filing such an application. The registration of a trademark may also be canceled in the event of the transformation of the trademark into a designation that has come into general use as a designation of goods of a certain type and in the event that the owner of the trademark renounces it;

- documents of protection require their maintenance. For the maintenance of a patent, a state fee is paid annually starting from the third year. Termination of payment of the state fee for maintaining the patent in force will entail the termination of its validity and, consequently, the termination of the exclusive rights of the copyright holder;

- the provisions of accounting for intangible assets provide that for intangible assets, for which it is impossible to determine the useful life, the rates of depreciation are set per 10 years. As practice shows, individual objects of intellectual property (especially in high-tech industries) can serve for more than 10 years. Very often they retain their relevance and relevance throughout the entire service life of a product made on their basis;

- the legal period of validity of property rights to computer programs and databases as objects of copyright is valid for the entire life and 50 years after the death of the copyright holder, and the right to IC topology - for 10 years. As practice shows, they quickly become obsolete and are used (have commercial potential) for a shorter period than the legal term of copyright.

Thus, there is no absolute certainty (as is the case when evaluating real estate or machinery and equipment) that the OIP remains commercially attractive to the consumer during the entire period of validity of exclusive rights. In this regard, for IP objects, especially if they are unique and relate to knowledge-intensive industries, it is impossible to accept the recommendations of national accounting standards 
(provisions) on the adoption of an amortization period of 20 years (but not more than the life of an enterprise) for intangible assets, by which it is impossible to determine the useful life.

According to International Valuation Standards, the useful life of an item of property, plant and equipment is defined as the expected period of time of its use or as the volume of production that is planned to be produced using this item. It is very problematic to determine the lost usefulness of the assessed rights to use OIP in monetary terms. We have developed the following gradation of the assessment of the lost utility in percentage (table 3 ).

Table 3.

The relationship between the stages of the innovation life cycle and the state of the OIP

\begin{tabular}{|c|c|c|c|}
\hline $\begin{array}{l}\text { Stages of } \\
\text { Life - } \\
\text { Foot cycle } \\
\text { innovation }\end{array}$ & $\begin{array}{l}\text { OIP } \\
\text { state }\end{array}$ & State characteristic & $\begin{array}{c}\text { The } \\
\text { degree } \\
\text { of lost- } \\
\text { term val } \\
\text { ues, } \%\end{array}$ \\
\hline $\begin{array}{l}\text { Creation of } \\
\text { innovation }\end{array}$ & New & $\begin{array}{l}\text { OIP represent the latest modern } \\
\text { results of scientific and technical } \\
\text { developments; on the fundamental } \\
\text { technical solutions embodied in } \\
\text { them, applications for legal } \\
\text { protection have been submitted and } \\
\text { there are positive decisions based } \\
\text { on the results of patent } \\
\text { examination; the product based on } \\
\text { them is completely new to the } \\
\text { market }\end{array}$ & $0-5$ \\
\hline \multirow[t]{2}{*}{$\begin{array}{l}\text { Industrial - } \\
\text { fief develop } \\
\text { ment }\end{array}$} & $\begin{array}{l}\text { Very } \\
\text { good }\end{array}$ & $\begin{array}{l}\text { OIPs are in excellent condition, } \\
\text { suitable for use for their intended } \\
\text { purpose; do not require } \\
\text { modernization or any changes in the } \\
\text { near future (within two to three } \\
\text { years); the technical solutions } \\
\text { proposed in them were recently } \\
\text { patented (the priority of the OIP is } \\
\text { no later than the third) the product } \\
\text { produced on their basis is new to } \\
\text { the market, where the demand for it } \\
\text { is just forming }\end{array}$ & $6-15$ \\
\hline & $\begin{array}{l}\text { Goo } \\
\mathrm{d}\end{array}$ & $\begin{array}{l}\text { OIPs have undergone minor } \\
\text { changes or upgrades to restore and } \\
\text { maintain their operational } \\
\text { properties; is used in accordance } \\
\text { with its purpose and technical and } \\
\text { economic characteristics; patented } \\
\text { technical solutions have not lost } \\
\text { their novelty and relevance; they are } \\
\text { used for serial production and } \\
\text { successful sale of products on the } \\
\text { market }\end{array}$ & $16-30$ \\
\hline \multirow[t]{2}{*}{$\begin{array}{r}\text { Slowed } \\
\text { down - of }\end{array}$} & $\begin{array}{l}\text { Satis } \\
\text { fying }\end{array}$ & $\begin{array}{l}\text { The characteristics of the OIP } \\
\text { meet the basic requirements for } \\
\text { ensuring the technical level and } \\
\text { industrial applicability; the main } \\
\text { technical solutions implemented in } \\
\text { them are still legally protected; OIP } \\
\text { require significant additions and } \\
\text { changes to improve and achieve a } \\
\text { modern technical level and } \\
\text { applicability; products made on } \\
\text { their basis are at the stage of market } \\
\text { saturation }\end{array}$ & $31-55$ \\
\hline & $\begin{array}{l}\text { Suita } \\
\text { ble } \\
\text { for use }\end{array}$ & $\begin{array}{l}\text { OIP is used below the degree of } \\
\text { its technical level and industrial } \\
\text { applicability due to the emergence } \\
\text { of new, more advanced patented } \\
\text { technical solutions; the term of legal } \\
\text { protection for the main technical }\end{array}$ & $56-80$ \\
\hline
\end{tabular}

\begin{tabular}{|c|c|c|c|}
\hline & & $\begin{array}{l}\text { solutions contained in them is at the } \\
\text { final stage (less than one year); OIP } \\
\text { require significant changes to the } \\
\text { claims in order to achieve the } \\
\text { modern technical level and } \\
\text { applicability; products made on } \\
\text { their basis are at the stage of market } \\
\text { stabilization }\end{array}$ & \\
\hline Recession & $\mathrm{Bad}$ & $\begin{array}{l}\text { OIP is used significantly below } \\
\text { the degree of its technical level and } \\
\text { industrial applicability due to the } \\
\text { emergence of new, more advanced } \\
\text { technical solutions that overlap the } \\
\text { existing technical solutions; the } \\
\text { term of legal protection for the main } \\
\text { technical solutions contained in } \\
\text { them has been exhausted; OIC } \\
\text { require a major revision or } \\
\text { replacement of existing technical } \\
\text { solutions with substantially new } \\
\text { ones; products made on their basis } \\
\text { are at the stage of declining demand } \\
\text { for them }\end{array}$ & $81-90$ \\
\hline $\begin{array}{l}\text { Withdrawa } \\
1 \\
\text { from produ } \\
\text { ction }\end{array}$ & $\begin{array}{c}\text { Not } \\
\text { fit } \\
\text { for Exe } \\
\text { cu- } \\
\text { mation } \\
\text { s (state } \\
\text { " Dispo } \\
\text { se- } \\
\text { tion ") }\end{array}$ & $\begin{array}{l}\text { OIPs cannot be used in practice, } \\
\text { despite the upgrades that can be } \\
\text { made; the term of patent protection } \\
\text { for basic technical solutions has } \\
\text { completely expired; the technical } \\
\text { solutions implemented in them are } \\
\text { fundamentally outdated in terms of } \\
\text { functionality; products made on } \\
\text { their basis are not in demand and } \\
\text { are not able to meet consumer } \\
\text { market requirements }\end{array}$ & $\begin{array}{c}91- \\
100\end{array}$ \\
\hline
\end{tabular}

Conclusions. The described approach was proposed to experts and used in the assessment of industrial technologies, the results of which generally coincide with the results of assessments obtained by other methods, which indicates the validity of the conclusions regarding their market value.

Thus, the approaches to assessing the loss of value of intellectual property and other intangible assets used in financial reporting and appraisal activities may differ significantly from each other. In order to prevent disagreements and ensure unambiguous reporting, appropriate reservations should be made and the application of certain methods should be regulated, depending on the purpose of using the results of identifying and unambiguous interpretation of such situations in the relevant assessment standards, accounting regulations and regulatory documents of tax accounting and IP value.

\section{References}

1. MARKET-BASED METHODS OF ESTIMATION OF LOSS OF VALUE INTELLECTUAL PROPERTY AT ENTERPRISES OF THE FUEL AND ENERGY SECTOR E3S Web of Conferences 216, 01174 (2020) . RSES

2020 . https://doi.org/10.1051/e3sconf/202021601174 .

2. Market methods of assessing the cost of the loss of intellectual property in Uzbekistan. Management in Russia and abroad. Moscow, No. 6, 2015. P.111-119 .

3. EFFECTIVE MANAGEMENT OF INTELLECTUAL CAPITAL OF THE COMPANY. // C ollection of scientific articles of international conference vii «the priority directions 
in the field of science and technology in xxi century», Korea , 2014 . P . 548-551.

4. Makhkamova M.A. Formation of an organizational and economic mechanism for managing innovative activities at mechanical engineering enterprises of the Republic of Uzbekistan. Doctor of Economics, T .: 2004.

5. Mamadzhanov Kh.A., Makhkamova M.A., Abbasova N.B. Innovative activity, assessment and use of intellectual property objects in the Republic of Uzbekistan. // Intellectual property, Industrial property., No. 11, 2002, P.4048, M. :, 2002 . 